\title{
THE LAPIS SATRICANUS AS EVIDENCE OF AN ITALIC WRITING CONTEXT IN THE LATIUM VETUS?
}

\author{
GIOVANNA ROCCA, GIULIA SARULLO (*)
}

RIASSUNTO. - Si proporrà una possibile individuazione culturale "sabina" del Lapis Satricanus, che si manifesta a livello di lingua e grafia. L'alfabeto latino presenta infatti alcune singolarità che richiamano possibili paralleli extra-latini. Ma ancora più significativi sono i contenuti "culturali" (compresi ovviamente i tratti linguistici), che paiono accennare ad una coesistenza di tradizioni a Roma di tipo "non romano".

$* * *$

ABSTRACT. - Sabine traditions in the Lapis Satricanus?

We will propose a possible cultural "sabine" individualization of the Lapis Satricanus, that expresses itself on a level of language and handwriting. The Latin alphabet actually gives evidence of some peculiarities that recall possible extra-Latin parallels. But the "cultural" contents (including obviously the linguistic features) are even more meaningful: these seem to show a coexistence of traditions in Rome of "not Roman type”.

(*) This work is the product of an intensive cooperation between the Authors. Giovanna Rocca (Università IULM - Milano) is responsible for paragraphs 1 and 3, whereas paragraph 2 is to be attributed to Giulia Sarullo (Università degli Studi di Enna "Kore"). We thought appropriate to begin in medias res in that Rocca 2009 offers an overview on the status quaestionis and an exhaustive linguistic and cultural study. 


\section{THE CIRCUMSTANCES OF THE FINDING AND THE FRACTURE OF THE STONE $[\mathrm{GR}](* *)$}

As it is well known, this inscription is carved on a block (Fig. 1) of stone recovered the $13^{\text {th }}$ of October 1977 in the area of the ancient Satricum, during the excavations made by the Dutch Institute in Rome, in the foundation of the second temple of Mater Matuta (about 500 $\mathrm{BC})$. It was found together with other two uninscribed blocks of the same kind of tuff stone (cappellaccio) that had been first discovered during the excavations of 1896 but remained partially buried.

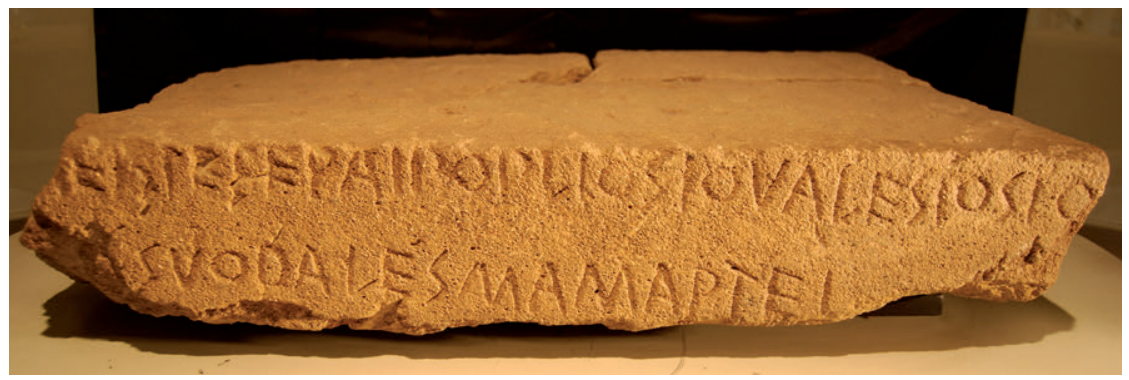

Fig. 1. The Lapis Satricanus at the Museo Nazionale Romano - Terme di Diocleziano (Photo by M. Muscariello).

The afternoon of October $13^{\text {th }}$ "the soil from the root-filled channel in front of the inscription was removed and the inward-facing side of the blocks became visible. The inscription was found upside-down on the centre block. Unfortunately the workmen proceeded with the removal of the earth in front of and on top of the stone on their own initiative, and some unnecessary and regrettable damage was caused by picks". ${ }^{1}$

Of this phase of the excavation a photo exists ("Once the position

${ }^{(* *)}$ I want to heartily thank my 'personal' translator, Giulia Sarullo, who has always taken care of translating my works (see lastly G. Rocca, Some Remarks on the Interference between Onomastics and Lexis, in "Linguarum Varietas" 2 (2013), pp. 223 234) $[\mathrm{GR}]$.

1 Stibbe 1980, p. 27. 
of the block with the inscription had been photographically documented and sketched...") in which the Lapis appears more extensively preserved on the upper left side than in the other pictures published up to then.

This picture, taken when the stone was still in situ (Fig. 2), clearly shows that there had been two moments of damage: the first one during the excavation and the second one during the extraction of the stone.

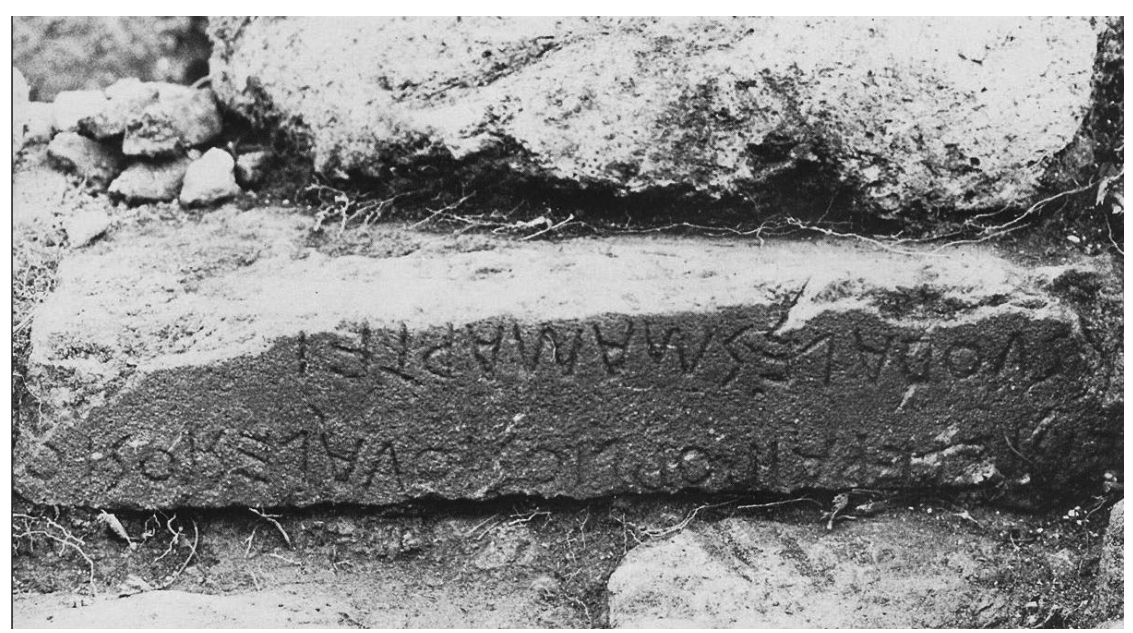

Fig. 2. The Lapis Satricanus in situ (Colonna 1995).

This picture was first published in 1991 by C. M. Stibbe and then by D. J. Waarsenburg in 1994. G. Colonna, ${ }^{2}$ through the observation of an enlargement of the corner in question, asserts that an $<\mathrm{i}>$ can be read: "Si osserva chiaramente che la scheggia d'angolo andata perduta conteneva la parte superiore del segno controverso, che è inequivocabilmente una $i$, ben conservata in tutto il suo sviluppo. [...]A sinistra della $i$ si intravede un'altra lettera, che sembra essere una $u$ asimmetrica, con il tratto destro più corto del sinistro, forse per preoccupazioni di spazio" ${ }^{3}$.

2 Colonna 1995. See also Table XLVII.

3 Contra Prosdocimi, who, after an autopsy, states that the stroke is less deep than all the other of the inscription, and Lucchesi-Magni 2002, p. 25 who describe it as 
The next year (1996) De Waele remarks "On a photo, made before the stone was removed he (i.e. Waarseburg) believed that he could distinguish the impression of the apex of a V-shaped letter. This observation is not correct, because it is due to the shadow of a grass-stalk" ${ }^{4}$

Furthermore, in the footnote in which he reported Waarseburg's work, De Waele adds that the enlargement of the photograph leads to the same conclusions.

In order to have new elements to study the question, we asked two scholars of the 'Department of Classics' and of the 'Department of Computer Science' of the University of Florida, Eleni Bozia and Angelos Barmpoutis, to perform an analysis on the photo of the Lapis Satricanus in situ making use of new technologies. Here are the results they obtained: "In order to read the less legible part of the inscription (bottom, right side of the picture), we applied a series of image processing algorithms. First, we blurred the image (using Gaussian kernel) in order to reduce the noise caused by the black and white dithering that was probably used during the printing of the image. ${ }^{5}$ We also increased the contrast of the image in the region of interest to make it clearer. Finally, we applied a method called anisotropic diffusion. ${ }^{6}$ The aforementioned method combines two processes that result in the blurring of the image with the simultaneous retaining of its local structures and discontinuities. The algorithm works by detecting the edges of the objects depicted in the image and then by blurring the regions in the image within the objects and along the edges. After applying the above algorithm on the Lapis Satricanus image, an inscribed structure of lines appeared before the letter $E$, which was not legible before the processing (see Fig. 3). It is possible, however, that some parts of the visible structure that we obtained after the processing may not correspond to an inscribed line, but to a dark spot in the image due to the poor lighting conditions and the bad quality of the picture" ?

a "traccia di un'asta verticale, dal ductus pressoché retto e parallelo alle aste verticali delle lettere successive, la cui profondità appare tuttavia inferiore a quella delle altre".

4 De Waele 1996, p. 233.

5 Dithering is the process of juxtaposing pixels of two colors to create the illusion that a third color is present.

6 See Black 1998.

7 Bozia-Barmpoutis 2009. 


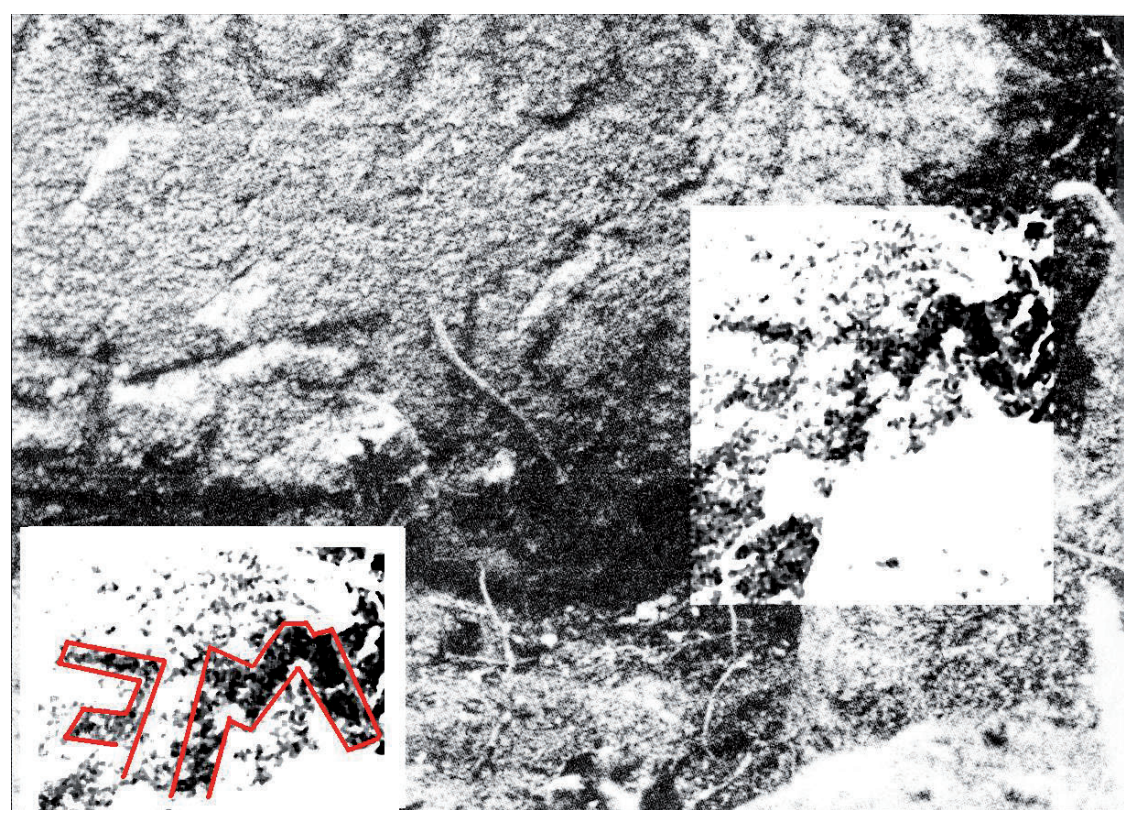

Fig. 3. Result of the anisotropic diffusion on the image published in Colonna 1995

(Bozia-Barmpoutis 2009).

In May 2009, within the Project "Iscrizioni Latine Arcaiche: a digital corpus of the archaic Latin inscriptions" and thanks to the availability and generosity of the Soprintendenti and of the consegnatari, we were allowed to take - together with the autoptic examinations of the materials - new photographs of the archaic Latin inscriptions preserved in Rome at the Museo Nazionale Romano alle Terme di Diocleziano and in other Roman Museums. In that occasion, the autopsy of the Lapis Satricanus confirmed the presence of a vertical stroke seen by means of a grazing light (Fig. 4).

Because of the fracture on the upper left side, the text is incomplete and it has thus been variously integrated. The hypothesis of the symmetrical order, suggested by Colonna, supposes that the second line is complete and that, because of the centring, at least four letters are missing at the beginning of the first line. Nevertheless, most of the attempts of integration do not consider this fact and give a three-letter integration, except 
Prosdocimi (1994) who proposes matr]ei. ${ }^{8}$ The main interpretations are: ].eisteterai: -(i)ei (nom. pl.) steterai (preterito): Acilliei, Soc]iei, Sal]iei, Iun]iei; ]..eisteterai: -(ui)ei Lai]uiei; ${ }^{9}$-]ei (dat. sing.) steterai (preterito): Matr] $i^{10}{ }^{10}$ ] (i)eis (dat. pl.) teterai (dat. pl.): Man]ieis teterai. ${ }^{11}$

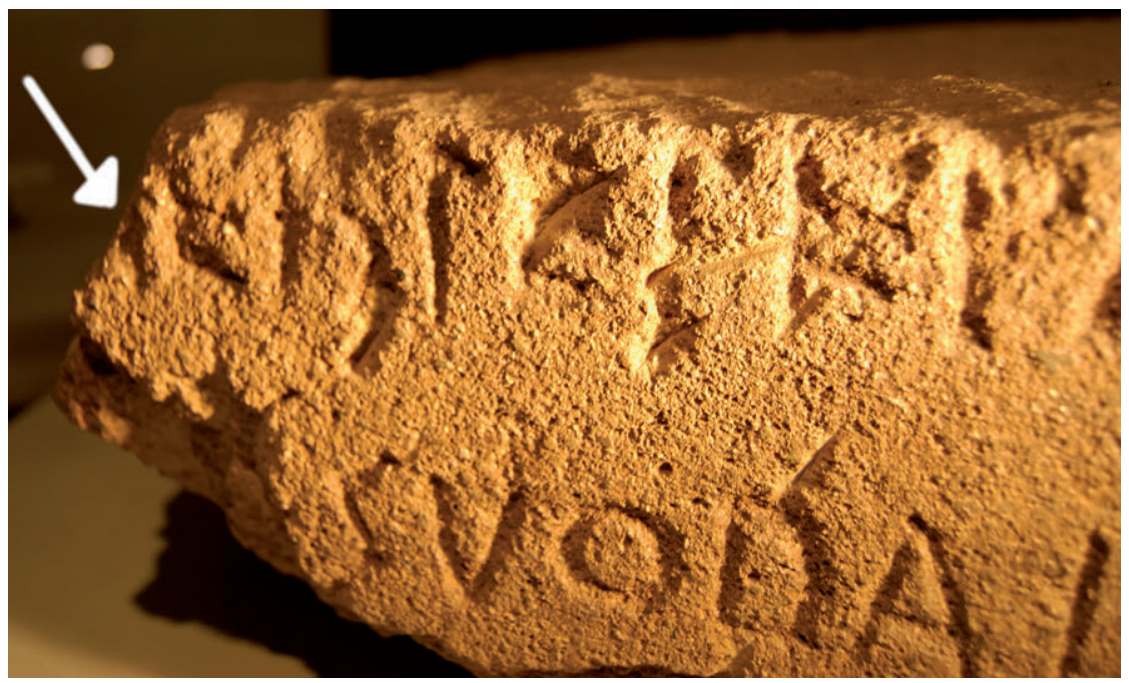

Fig. 4. Close up of the Lapis Satricanus illuminated by a grazing light.

The white arrow indicates the vertical stroke (Photo by M. Muscariello).

If Colonna's hypothesis fails (a first example of the symmetrical order appears in the $4^{\text {th }}$ century $\mathrm{BC}$ in Rome, but it will become more common only in the $3^{\text {rd }} \mathrm{BC}$ ), it will be necessary to admit a lacuna for the second line as well.

8 A general overview was presented in Lucchesi-Magni 2002, pp. 83-85, where the integrations proposed since 1978 are listed. Up to the Nineties, also a 'pronominal' hypothesis existed. For the second segment, both the hypotheses of a theonym Mamartei (dat. sing.) and of an adjective *mamarteus (nom. pl.) have been proposed.

9 De Simone 1980; Guarducci 1980; De Waele 1981 and 1996, Campanile 1985, Silvestri 1993 with the variant Steterai = Steterae 'supporter'; Versnel 1997; Colonna 1996.

10 Prosdocimi 1994.

11 Coarelli 1995. 


\section{EPIGRAPHIC COMPARISONS [GS]}

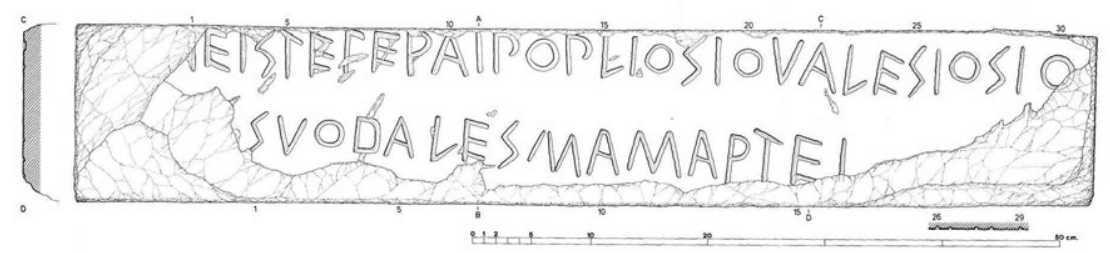

Fig. 5. Apographon of the inscription (Colonna 1980).

The inscription presents left-to-right ductus and scriptio continua. The letters that appear more than once do not show relevant modifications in their shape; ${ }^{12}$ this is a first indication of the accuracy with which the inscription was engraved and confirms that we are dealing with a highly professional scribe, which certainly suits a public text of this importance.

We are going to compare the morphological characteristics of the letters on the Lapis Satricanus ${ }^{13}$ with those attested on some inscriptions from Latium Vetus. ${ }^{14}$ In this regard, we present two tables of comparison in which the results of our overview are summarized. ${ }^{15}$

A (5): ${ }^{16}$ of triangular shape, always with a descending cross-stroke according to the direction of writing. As Giovanni Colonna remarks, ${ }^{17}$

12 The same cannot be said of the Forum Inscription and the Duenos Inscription, that show morphological variations for the most frequent letters. A table of the different shapes of the alphabetical signs attested on the Forum Inscription can be found in Urbanová 1999.

13 The first epigraphic description of the Lapis Satricanus was published in Colonna 1980.

14 The letter $<\mathrm{i}>$ has not been included in our comparison in that this letter, that occurs 6 (or 7) times in the Lapis Satricanus, does not show any significant variation in the archaic Latin inscription.

15 In the tables, each inscription corresponds to a number, which is the same that has been used in the text of the appendix; the number is preceded by TT and enclosed in round parentheses; for example, (TT7)=Tables, n. 7, and so on.

16 The number enclosed in round parentheses indicates the number of times each letter occurs on the Lapis Satricanus.

17 Colonna 1980, p. 43. 
"una caratteristica costante è l'inclinazione verso destra, nella direzione della scrittura, di tutte le linee trasversali (della $A$, della $E$ e della $T$ )". This characteristic is evident especially in the $\langle\mathrm{a}\rangle$ and the $\langle\mathrm{t}\rangle$; we notice this phenomenon also on the altar fragments from Corcolle (TT7), which have been considered a fundamental term of comparison for our inscription since its discovery, and in three other archaic inscriptions: ${ }^{18}$ the bowl from Garigliano (TT4), the bowl Bernardini from Praeneste $^{19}$ (TT5) and the urn from Gabii (TT8).

The only $\mathbf{D}$ on the Lapis Satricanus shows a round arch that widens in the lower part, rather wide in comparison with the other exemplars of the same letter in the archaic Latin inscriptions.

E (6): the vertical stroke extends beyond the base of the letter, the cross-strokes are descending. The common type in the archaic Latin inscriptions (and not only there) is the <e> with an extended vertical stroke over the bottom and the top; the vertical stroke that extends only over the bottom is attested on the inscription from Garigliano (TT4), on the altar fragments from Corcolle (TT7), on the urn from Caere (TT9), on the Lamina from Lavinium (TT10) and on the Forum Inscription (TT15).

L (3): the horizontal stroke is quite long and forms an acute angle with the vertical stroke; this angle is slightly wider than, for example, the one on the fragment B of the dolium from Satricum (TT3) and the lamina from Lavinium (TT10).

M (2): the four-stroke $<m>$ is one of the letters that characterize the Lapis, in that in the most ancient Latin epigraphs there is constantly a five-stroke $<\mathrm{m}>.^{20}$ Nevertheless, there is a four-stroke $<\mathrm{m}>$ on a graffito from the Roman Forum dating to the last quart of the $6^{\text {th }}$ century $\mathrm{BC}$, that is contemporary with our inscription, as well as on the altar fragments from Corcolle (TT7), the inscription from Garigliano (TT4) - although here the comparison is less striking -, on the Lapis

18 The lacking of coherence in the inclination on the Satrican fragment adeua (TT2) can be due to the antiquity of the text itself (725-650 BC).

19 The latinity of this document is still doubtful. For an overview on the subject, see Hartmann 2005, pp. 37-66.

20 Colonna 1980, p. 48, reminds that "la $M$ a cinque tratti di tradizione euboica, [...] sporadicamente sopravvive fin nel IV secolo e, come sigla del prenome Manius, fino in età imperiale". 
Tiburtinus (TT6) - which also attests a five-stroke $<\mathrm{m}>-$, in manias of the pitcher from Acqua Acetosa Laurentina (TT14) and, upside-down, on the abecedarium from Lanuvium. ${ }^{21}$

$\mathbf{O}$ (6): constantly rounded and smaller than the other letters. An $<0>$ of similar dimensions is quite common in the archaic inscriptions, also in the Latin ones: the altar fragments from Corcolle (TT7), the tile from Acqua Acetosa Laurentina (TT13), the lamina from Lavinium (TT10), the vase from Ardea (TT11), the Forum Inscription (TT15), the Duenos Inscription ${ }^{22}$ (TT16) and the fragment from the Roman Forum with trepios $^{23}$ (TT17). In the Lapis Tiburtinus (TT6) the <o> appears as a point.

P (2): round open, "arcuata". Giovanni Colonna judged this graphic form ${ }^{24}$ "recenziore rispetto alla $P$ ad uncino delle iscrizioni del Foro e di Tivoli, rispecchiante l'uso comune etrusco, e quella angolosa del vaso di Duenos". "P arcuata" is also well attested in some epigraphic documents that are contemporary with the Lapis: the altar fragments from Corcolle (TT7), the inscription from Garigliano (TT4), the tile from Acqua Acetosa Laurentina (TT13) and the lamina from Lavinium (TT10); furthermore, it is also present in some graffiti dating to the $6^{\text {th }}$ century BC..$^{25}$

$\mathbf{R}$ (2): in the shape of rho, with a small, round, closed bow; it is similar to the one on the fragment A of the dolium from Satricum (TT3), which shows a small, round, closed ansa. $<\mathrm{r}>$ in the shape of $r h o$ and with round bow is also spread among the archaic Latin inscriptions, that present an angular $<\mathrm{r}>$ only in few examples, such as on the inscription from Garigliano (TT4).

S (6): it is one of the signs that are more frequent on the Lapis; it is constantly three-stroke, quite angular and always progressive as regards to the ductus of the inscription. Retrograde $<\mathrm{s}>$ occurs on some inscriptions dating to the $7^{\text {th }}$ century BC, as the urn from Caere (TT9),

21 See L. Attenni, D. F. Maras, 2005.

22 In the Forum Inscription (TT15) and in the Duenos Inscription (TT16) < $>$ of smaller dimensions coexists with a bigger one.

23 See Fortini 2005.

24 Colonna 1980, p. 48.

25 Because of its doubtful interpretation $(<0>,<\mathrm{d}\rangle,\langle\mathrm{p}\rangle)$, the second sign of line $\mathrm{f}$ in the Lapis Tiburtinus (TT6) cannot be included into this analysis. An overview of the question was recently presented in Muscariello in print. 
the bowl Bernardini from Praeneste (TT5), and the tile from Acqua Acetosa Laurentina (TT13); moreover, it is well attested on documents dating to the $6^{\text {th }}$ century BC, as the Forum Inscription (TT15) and on some fragmentary documents: dolium from Satricum (TT3), trepios (TT17) and bios (CIL I² $2916 \mathrm{k}$ a) from the Roman Forum, ououios from the sacred area of Sant'Omobono (CIL I ${ }^{2} 2829$ ) and the abecedarium from Lanuvium (see note 21 ). As regards to the $5^{\text {th }}$ century, the only example of an $<\mathrm{s}>$ drawn in a ductus opposite to the direction of writing is on the bowl from Garigliano (TT4), where, in one occurrence out of four, there is a three-stroke retrograde $<\mathrm{s}>{ }^{26} \mathrm{~A}$ remarkable case is attested on the vase from Ardea eqo kanaios (TT11), where the fourstroke $<$ s $>$ seems to be retrograde.

T (3): it always has a descending, according to the direction of writing and quite long cross-stroke. Similar examples can be found on the bowl from Garigliano (TT4), the urn from Gabii (TT8) and the altar fragments from Corcolle (TT7). In other epigraphic documents, the horizontal segment of the $<t>$ is shorter, as in the urn from Caere (TT9), the tile from Acqua Acetosa Laurentina (TT13) and the lamina from Lavinium (TT10), where the horizontal stroke is also ascending.

V (2): it constantly shows symmetrical strokes and has no extension, a characteristic also present on the fragment B of the dolium from Satricum (TT3), on the altar fragments of Corcolle (TT7), on the lamina from Lavinium (TT10) and on some occurrences of the Forum Inscription (TT15).

This comparative analysis shows a significant consistency between the Lapis Satricanus and some inscriptions coming from the south-eastern borders of the Latium vetus: the bowl from Garigliano (TT4), the altar fragments from Corcolle (TT7), the Lapis Tiburtinus (TT6). ${ }^{27}$ It also seems to point to the presence of a "different" writing in an area that will later acquire the Latin writing. The smaller $<0\rangle$, that on the Lapis Tiburtinus appears as a point, is quite common in the archaic

26 Moreover, it has to be noticed that, in all the cases above mentioned, besides the abecedarium from Lanuvium (see above, n. 21), we are dealing with a three-stroke $<\mathrm{s}>$ (see the Tables of comparison below).

27 Among the inscriptions that have been found in Rome dating to the archaic period, the graffito from the Roman Forum with trepios (TT17) shows interesting (epi)graphic correspondences with the Lapis Satricanus (TT1). 
inscriptions, not only in this area: in South-Picene, the $<0>$ is always rendered as a point (not distinguishable from the dividing point) and represents the point of arrival of a writing tradition (Latin-Sabine?) that tends to simplify the circular graphs in a point (see also the $\langle\mathrm{f}\rangle$ in the shape of an $\mathbf{8}$ rendered as two points:).

\begin{tabular}{|c|c|c|c|c|c|c|c|c|c|c|c|c|}
\hline 1 & Lapis Satricanus (end 6 th - first half $5^{\text {th) }}$ CIL $122832 a$ & A & $D$ & $E$ & L & $M$ & 0 & $P$ & $P$ & S & $T$ & V \\
\hline 2 & Fragment from Satricum (725-650)Colonna-Beijer 1992 & $A$ & D & $E$ & & & & & & & & X \\
\hline 3 & Dolium from Satricum (575-535) Gnade-Colonna 2003 & $A$ & & & $\ell$ & M & $Q$ & $?$ & क & $\sum$ & & V \\
\hline 4 & Bowl from Garigliano $(500-480)$ & A & $D$ & E & & $M$ & 0 & $\Gamma$ & p & $\sum \$$ & $T$ & $y$ \\
\hline 5 & Bowl Bernardini, Preneste ( $7_{\text {th }}$ ) & $F$ & & $\exists$ & & & & & & S & $T$ & V \\
\hline 6 & Lapis Tiburtinus (500 ca) & A & 0 & $\lambda$ & 1 & M & - & & 9 & 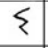 & $T$ & $\mathbf{V}$ \\
\hline 7 & Altar fragments from Corcolle (end $7^{\text {th- }} 6^{\text {th }}$ ) CIL & A & D & $E$ & L & $M$ & 0 & $\Gamma$ & P & S & $T$ & V \\
\hline 8 & Urn from Gabii, Osteria dell'Osa (630-600) Hartmann 2005 & $A$ & $\mathbb{S}$ & E & $y$ & & 7 & & & \{ & $T$ & Y \\
\hline 9 & Urn from Caere (630-600) & $A A$ & D & $E$ & & $M$ & & & $P$ & 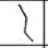 & $T$ & $Y$ \\
\hline 10 & $\left.-5^{\text {th }}\right) \quad$ CIL I22833 & A & 0 & 丰 & $J$ & & 0 & 7 & 9 & 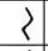 & $\uparrow$ & V \\
\hline 11 & Vase from Ardea (560-480) & $A$ & & $E$ & & & $\diamond$ & & & 3 & & \\
\hline 12 & 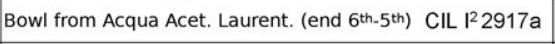 & A & & & & & 0 & & p & $\zeta$ & & \\
\hline 13 & Tile from Acqua Acet. Laurent. (end $7^{\text {th-6th) }}$ CIL I2 & $R$ & & & & & 2 & q & 4 & $>$ & $\pi$ & \\
\hline 14 & -5th) CIL & A & & & & M & & & & $\zeta$ & & \\
\hline 15 & Forum Inscription (575-550) & A & D & E & $L$ & M & 0 & 1 & 9 & $S$ & $T$ & $\mathbf{V}$ \\
\hline 16 & Duenos Inscription (first half 6 th) & A & 0 & 录 & 7 & $M$ & 0 & $\uparrow$ & 8 & 2 & 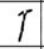 & Yr \\
\hline 17 & Fragment from the Roman Forum (end $6^{\text {th }}-5^{\text {th }}$ ) Fortini 2005 & & & $k$ & & & D & $p$ & $p$ & 3 & $T$ & \\
\hline
\end{tabular}

Tab. 1. Graphical reproduction of the shapes of the letters attested on the Lapis Satricanus and of the corresponding letters on some archaic Latin inscriptions $\left(7^{\text {th }}-5^{\text {th }}\right.$ century BC). Starting from Satricum, it proceeds geographically anticlockwise towards Rome. For the inscriptions that are not in CIL the most recent bibliographical reference is quoted. 


\begin{tabular}{|c|c|c|c|c|c|c|c|c|c|c|c|c|c|c|c|c|c|}
\hline Graphic characteristics & 1 & 2 & 3 & 4 & 5 & 6 & 7 & 8 & 9 & 10 & 11 & 12 & 13 & 14 & 15 & 16 & 17 \\
\hline A ascending cross-stroke & & + & & & & + & & & + & + & + & & + & + & + & + & \\
\hline descending cross-stroke & + & & + & + & + & & + & + & + & & & + & & & + & + & \\
\hline D round & + & & & + & & + & + & & & + & & & & & + & + & \\
\hline angular & & + & & & & & & + & + & & & & & & & + & \\
\hline E extended vertical stroke top & & + & & + & & & & + & + & & + & & & & & + & + \\
\hline bottom & + & + & & + & + & + & + & & + & + & + & & & & + & + & + \\
\hline descending strokes & + & + & & + & + & + & & + & + & + & + & & & & + & + & + \\
\hline strokes of different length & + & + & & + & + & & + & + & & & + & & & & + & + & + \\
\hline L acute angle & + & & + & & & + & + & + & & + & & & & & + & & \\
\hline angle on top & & & & & & + & & & & & & & & & & & \\
\hline M four-stroke & + & & & + & & + & + & & & & & & & + & & & \\
\hline five-stroke & & & + & & & + & & & + & & & & & & + & + & \\
\hline strokes of same length & + & & & + & & + & + & & & & & & & + & + & + & \\
\hline longer first stroke & & & + & & & & & & + & & & & & & + & + & \\
\hline O big & & & + & + & & & & & + & & & & & & & + & \\
\hline small & + & & & + & & + & + & & & + & + & & + & & + & + & + \\
\hline round & + & & + & + & & & + & & & + & & + & & & + & + & \\
\hline angular & & & & & & & & + & + & & + & + & + & & & + & + \\
\hline $\mathbf{P}$ open & + & & + & + & & & + & & & + & & & + & & + & + & + \\
\hline round & + & & & + & & & & & & + & & & + & & + & & + \\
\hline angular & & & + & & & & + & & & & & & & & & + & \\
\hline $\mathbf{R}$ round & + & & + & & & + & + & & + & + & & & + & & + & + & + \\
\hline angular & & & & + & & & & & + & & & + & & & & & \\
\hline $\mathbf{S}$ three-stroke & + & & + & + & + & + & + & & + & + & & + & + & + & + & + & + \\
\hline four-stroke & & & & + & & + & & + & & & + & & & & & & \\
\hline $\mathbf{T}$ ascending cross-stroke & & & & & + & & & & & + & & & + & & + & + & \\
\hline descending cross-stroke & + & & & + & & & + & + & + & & & & & & + & + & + \\
\hline Ductus & $>$ & $>$ & 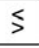 & $>$ & $<$ & 0 & $>$ & $>$ & $>$ & $<$ & $>$ & $>$ & $<$ & $>$ & $\lesseqgtr$ & $<$ & $>$ \\
\hline Punctuation & & & & & & & $:$ & & & : & & & & & : & & \\
\hline Scriptio continua & + & + & + & + & + & + & & + & + & + & + & + & & + & & + & + \\
\hline
\end{tabular}

Tab. 2. Synopsis of the characteristics of each sign in terms of presencelabsence.

The numbers correspond to the inscriptions in Tab. 1. 


\section{WRITING CONTEXTS [GR]}

As it has been shown, the form of some of the letters (the $<a>$ with a descending cross-stroke according to the direction of writing, the four-stroke $\langle\mathrm{m}\rangle$, the $\langle\mathrm{o}\rangle$ of smaller dimensions, the open $\langle\mathrm{p}\rangle$, the $\langle\mathrm{r}\rangle$ in the shape of $r b o$, the three-stroke $\langle\mathrm{s}\rangle$, the $\langle\mathrm{t}\rangle$ with a transversal descending stroke) typical of the archaic Latin epigraphic production, seems to allude to a "non Roman" writing context with possible interferences of pre-Latin writing patterns.

The phenomenon of flowing or influence of graphical usage from one writing system to another is well-known and common. A complex picture and a fluidity of the alphabetic system were already highlighted by M. Cristofani as regards to the archaic epigraphic documents that cannot be ascribed to a single model but to two writing contexts that are geographically localized. In comparison with the context of Rome, where the Forum Inscription and of the Duenos Inscription were produced (that is with "un foyer scrittorio in apparente sviluppo nel corso del VI sec. a.C."): "il primo orientale [...] adotta un sistema che deriva dall'etrusco meridionale... Il secondo, che considererei settentrionale rispetto a Roma, per le sue connessioni con l'ambiente scrittorio veiente". ${ }^{28}$ Before the linguistic component, the writing is the first feature that recalls varieties that were present in the Latium vetus, and in Rome itself, during the $6^{\text {th }}$ century BC.

With regard to varieties, it is worth mentioning the affinity, never noticed by others, of the form mamartei for mamertei (on the Lapis Satricanus) and muliar for mulier (on the altar fragments from Corcolle). Muliar cannot be compared with mulies, the antecedent of mulier, as can be supposed by the derivative muliebris from "mulies-ris. As to the morphological aspect, a heteromorphy can be postulated: mulier is the continuation of both muliar and mulies (ancient neuter?), a remnant of derivation later converged in a single system. In this view, this is not a non Latin form, but a Latin form that has to be defined. The form mamar- is not isolated but it has been recently confirmed by the mamarcom engraved on one of the three fragments of a dolium dating to the 575-525 $\mathrm{BC}$ that were found in the north-east area of the acropolis of ancient Satricum. ${ }^{29}$ This inscription shows some characteristics that offer a pre-

28 Cristofani 1993, pp. 26-27.

29 Gnade-Colonna 2003. 
cious support to the hypothesis of the existence of 'non-Roman' writing contexts we mentioned above. Fragment A bears an inscription on the shoulder of the vase engraved before firing in scriptio continua: ]-AMAMAR/COMPLACIOM-[; G. Colonna describes the ductus as boustrophedic. Fragment B reads: ]LOUCIOS C[; the ductus is left-to-right but with a retrograde $<\mathrm{s}>$. The latter and the preceding $<\mathrm{o}>$ are the only clearly legible letters in that the text is partially damaged, not only in the extremities but also in the lower part; only the upper part of the first five letters is visible. Fragment $C$ preserves only one letter $(<\mathrm{u}>$ or $<\mathrm{a}>)$ that was presumably engraved on the lower part of the vase, as the thickness of the fragment would suggest. The space between the extremities leads to the assumption that we are dealing with an isolated letter and this is why Colonna interprets it as the number V: the dolium would be the fifth of a numbered series of vases.

According to G. Colonna, the ductus is quite extraordinary, in that it is a kind of boustrophedon that was not common in the Latin and Italic area ("un ricordo della pratica della scrittura a serpentina, o 'Schlangenschreibung' da riferirsi a tradizione greca"), whereas the scriptio continua would be common, as regards the Latin inscriptions on vase. An analogous kind of ductus is attested on the Forum Inscription (imperfect boustrophedon), ${ }^{30}$ the Lapis Tiburtinus (in which the frequent changes of the direction of writing and the presence of upside-down letters would be evidence of an "ambiente scrittorio 'impreciso' in via di assestamento", according to Mancini) ${ }^{31}$ and the altar fragments of Corcolle (in which some letters are slightly rotated). All these inscriptions date to the $6^{\text {th }}$ century BC and could constitute a term of comparison for our hypothesis of a common writing context. ${ }^{32}$

If we postulate a scribe (or more than one) of non-Latin language and alphabet that write in a Latin language and alphabet we can explain the imperfect boustrophedic writing. The comparisons, as it has been said, exist, also in a later period: the lamina of Caso Cantovio, dating to the \pm 300 BC, was written in Latin and with a Latin alphabet, but the ductus is boustrophedic, though not exempt of mistakes: the $<\mathrm{s}>$ of the

30 The imperfect ductus of the Forum Inscription, in relationship with diffusion of the boustrophedon in Italy and Greece, has been recently analyzed in Sarullo in print.

31 Mancini 1979, p. 373.

32 Since it is considered a lex arae, the altar fragments of Corcolle, being an 'official' text, would show the penetration of this writing context up to a 'high' level. 
second line is retrograde as regards to the direction of writing $(<\mathrm{s}>$ is left-to-right, while the rest of the line is right-to-left); between lines 3 and 4 there is no change of direction, as the boustrophedon would require; the first letter of line $5,<b>$, is left-to-right while the rest of the line is right-to-left. In fact, the different orientation of some letters on the Lapis Satricanus, "con la lettera n. 5 ruotata in avanti a $45^{\circ}$ " and the "n. 8 calata in basso e leggermente ruotata in avanti", can be considered. According to L. Del Tutto, this kind of boustrophedon, unusual in the Latin area, with the exception of the Forum Inscription, and in the Italic area, "dirige la ricerca di possibili interferenze verso moduli scrittorii precedenti al latino, in area che sarà poi marsa e nelle aree prossime, con analogie grafiche evidenti: si può e si deve pensare al sudpiceno, prima come grafia, poi come lingua". ${ }^{33}$

In South-Picene, the kind of ductus is peculiar and for this reason without compare: Marinetti remarks that "non è infatti identificabile puntualmente con modelli greci, né col boustrophedon, in cui le linee si susseguono parallele ma le lettere non vengono capovolte, né con la Schlangeschrift, o serpentina in cui le lettere vengono capovolte a linee alterne, in modo da presentare sempre la stessa direzione (destra $\rightarrow$ sinistra o viceversa) a seconda del lato in cui inizia l'iscrizione". ${ }^{34}$ In comparison with the inscriptions in Latin writing, the South-Picene inscriptions are characterized by the alternation of the letters from left to right (and top and bottom) with no trace of uniformity or evident rules; this phenomenon depends on the graphic usus of the strophedon, as the presence of retrograde letters in a left-to-right text shows, that is evidence of a writing that is indifferent to the orientation of the letters. It is now certain that South-Picene has a strong connection with Sabine, as the Safini from Penna S. Andrea and the inscription on the cippus from Cures discovered in a Sabine area but with a South-Picene writing confirm.

We would then have a link between all these inscriptions ${ }^{35}$ (and

33 Del Tutto 2002, p. 443. The occurrences of boustrophedon in Italy are analyzed in Sarullo in print.

34 Marinetti 1985, p. 58.

35 Perhaps also the right-to-left ]rsi from the area of Cerchio (AQ) with a leftto-right $\langle\mathrm{s}\rangle,\langle\mathrm{r}\rangle$ with triangular bow in the same shape as the South-Picene ones and of the $<\mathrm{p}>$ on the Caso Cantovio inscription. See Marinetti 1985, p. 261. 
Forum Inscription?), a link that is represented by the perspective of a scribe - used to certain shapes of letters and to the alternating ductus who writes in a variety of language that could, or could not, be his own. The Lapis Satricanus is perhaps the testimony of a moment of transition - vestiges in the shape of the letters? - from the 'writing x (Sabine $\rightarrow$ South-Picene)' to the 'Latin writing' that show either a phase of adaptation or a precise choice of cultural self-determination.

We realize that to any proposal objections can be moved: here, for example, as well as in South-Picene, the hypothesis of a writing adapted to the material according to the logic of the 'graphical semantics' has been taken into consideration, but the utility of our attempt resides, with all the due methodological precautions, in the search for a solidarity that could gather disiecta membra into 'members of a class'. The Sabine character could then surface also at the graphical level. 


\section{REFERENCES}

L. Attenni, D. F. Maras, Materiali arcaici dalla collezione Dionigi di Lanuvio, in «St. Etr.» LXX, 2005, pp. 68-78.

Ph. Baldi, The Foundations of Latin, Berlin/New York, Mouton de Gruyter, 1999.

F. Barnabei, R. Mengarelli, Conca. Nuovi scavi nel tempio satricano di Mater Matuta, scoperte sulla collina presso Le Ferriere di Conca, «NSc» (1896), pp. 190-200.

M. J. Black, G. Sapico, D. Marimont, D. Heeger, Robust anisotropic diffusion, in IEEE Trans. on Image Processing, 1998, vol. 7(3), pp. 421-432.

R. Bloch, Á propos de l'inscription latine arcaïque trouvée à Satricum, «Latomus», 42 (1983), pp. 362-371.

T. Bolelli, Considerazioni sul genitivo latino della seconda declinazione, «Rend. Dell'Acc. d'Italia» serie 7, 4 (1942), pp. 49-59.

G. Bonfante, La nuova iscrizione di Satricum e il genitivo in -osio, «Rend. Lincei» serie VIII, XXXIII (1978) [1979], pp. 269-272.

E. Bozia, A. Barmpoutis, Computer Assisted Study of the Inscription, «Alessandria» 3 (2009), pp. 90-91.

F. Coarelli, Roma. I Volsci e il Lazio antico, in Crise et transformation des sociétés archä̈ques de l'Italie antique au Ve siècle av. J.-C., Actes de la table ronde (Rome, 19-21 novembre 1987), École Française de Rome, pp. 135-154.

F. Coarelli, Vino e ideologia nella Roma arcaica, in O. Murray, M. Tecuxan (a c. di), In vino veritas, London, British School at Rome, 1995, pp. 196-213.

F. Coarelli, Il Campo Marzio: dalle origini alla fine della Repubblica, Roma, Quasar, 1997.

R. Coleman, The central italic Languages in the Period of Roman Expansion, «Trans. Philol. Society» 1986, pp. 100-131.

G. Colonna, L'aspetto epigrafico. Appendice: le iscrizioni strumentali latine del VI e V sec. a.C., in C. M. Stibbe, G. Colonna, C. De Simone, H.S. Versnel, Lapis Satricanus. Archaeological, epigraphical, linguistic and historical aspects of the new inscription from Satricum, Archeologische Studien van het Nederlands Instituut te Rome, Scripta Minora V, Staatsuitgeverij - 's-Gravenhage, The Hague,1980, pp. 41-69.

G. Colonna, A. J. Beijer, Un'iscrizione latina di VII secolo da Satricum, «REI» in «St. Etr.» LVIII (1992), pp. 316-320.

G. Colonna, Ancora sul Lapis Satricanus, «REI» in «St. Etr.» LXI (1995), pp. 350-351.

G. Colonna, Dolio con iscrizioni latine arcaiche da Satricum, «Archeologia Classica» LIV (2003), pp. 13-19.

G. Colonna, Le iscrizioni di Satricum, in M. Gnade (a c. di), Satricum. Trent'anni di scavi olandesi, Catalogo della Mostra. Le Ferriere - Latina, 26 ottobre 2007-28 febbraio 2008, Amsterdams Archeologisch Centrum, Università di Amsterdam, pp. 98-99 e 194-197.

M. Cristofani, Blocco iscritto da Satricum, in M. Cristofani (a c. di), La grande Roma dei Tarquini, Catalogo della Mostra, Roma 1990, pp. 23-24.

M. Cristofani, Le prime iscrizioni latine dell'Etruria, in E. Campanile (a c. di), Caratteri e diffusione del latino in età arcaica, Pisa, Giardini, 1993. 
C. De Simone, A proposito della nuova iscrizione latina arcaica di Satricum. Interventi sulla comunicazione del dott. Stibbe, «Archeologia Laziale» I («QuadAEI» I) (1978), pp. 95-98.

L. Del Tutto, L'iscrizione di Caso Cantovio, in L. Del Tutto, A.L. Prosdocimi, G. Rocca, Lingua e Cultura intorno al 295 a.C.: tra Roma e gli Italici del Nord, Roma, ed. Il Calamo, pp. 418-447 in D. Poli (a c. di), La battaglia del Sentino. Scontro fra nazioni e incontro in una nazione, Atti del Convegno, Camerino-Sassoferrato 1013 giugno 1998, in Quaderni Linguistici e Filologici XIV, 2002, Università di Macerata, Roma, Il Calamo, 2002.

C. De Simone, L'iscrizione latina arcaica di Satricum. Problemi metodologici ed ermeneutici, «Giornale Italiano di Filologia», XII (1981), pp. 25-56.

C. De Simone, Sul nuovo frammento iscritto arcaico di Satricum, in «Rivista di Filologia» 121 (1993), pp. 285-288.

C. De Simone, Ancora sull'iscrizione satricana di P. Valerio, «St. Etr.» LXI (1995), pp. 247-253.

C. De Simone, Il Lapis satricanus quindici anni dopo, in M. Gnade - E. M. Moormann (a c. di) Satricum 1896-1996. Atti del convegno internazionale in occasione del primo centenario degli scavi a Satricum, Roma 1996, «MededRom» 56 (1997), pp. 201-203.

J. A. De Waele, The Lapis Satricanus and the Chronology of the temple of Mater Matuta at Satricum, «Ostraka» V, 2 (1996), pp. 231-242.

J. A. De Waele, Cronologia e architettura dei templi della Mater Matuta, in M. Gnade E. M. Moormann (a c. di), Satricum 1896-1996. Atti del convegno internazionale in occasione del primo centenario degli scavi a Satricum, Roma 1996, «MededRom» 56 (1997) pp. 69-83.

P. Fortini, Una nuova iscrizione latina arcaica dal Foro Romano (area del cd. Equus Domitiani), in D. Chiazza (a c. di), Italica ars. Studi in onore di Giovanni Colonna per il premio I Sanniti, Piedimonte Matese (CE), Arti Grafiche Grillo, 2005, pp. 267-276.

M. Gnade, Dolio con iscrizioni latine arcaiche da Satricum, «Archeologia Classica» LIV (2003), pp. 1-12.

M. Gnade (a c. di), Satricum. Trent'anni di scavi olandesi, Catalogo della Mostra. Le Ferriere - Latina, 26 ottobre 2007-28 febbraio 2008, Amsterdams Archeologisch Centrum, Università di Amsterdam.

M. Guarducci, L'epigrafe arcaica di Satricum e Publio Valerio, «Rend. Lincei» serie VIII, XXXV (1980) [1981], pp. 479-489 + 2 tavv.

M. Hartmann, Die früblateinischen Inschriften und ibre Datierung, Bremen, Hempen, 2005.

R. Knoop, P. Lulof, L'architettura templare, in M. Gnade (a c. di), Satricum. Trent'anni di scavi olandesi, Catalogo della Mostra. Le Ferriere - Latina, 26 ottobre 200728 febbraio 2008, Amsterdams Archeologisch Centrum, Università di Amsterdam, pp. 32-42.

C. Letta, S. D’Amato, Epigrafia della regione dei Marsi, Milano, Cisalpino, 1975.

M. Lejeune, Notes sur la Dédicace de Satricum, «REL» 67 (1990), pp. 60-63. 
E. Lucchesi, E. Magni, Vecchie e nuove (in)certezze sul Lapis Satricanus, Pisa, ETS, 2002.

A. Mancini, L'iscrizione sulla base di Tivoli CIL I2, 2658. Nuova lettura, «REI» in «St. Etr.» XLVII (1979), pp. 370-375.

M. Mancini, Latina Antiquissima II: ancora sull'epigrafe del Garigliano, in V. Orioles (a c. di), Studi in memoria di Eugenio Coseriu, Supplemento a Plurilinguismo. Contatti di lingue e culture 10, Udine, 2003, pp. 229-251.

D. Maras, Novità sulla diffusione dell'alfabeto latino nel Lazio arcaico, in F. Mannino M. Mannino - D. Maras (a c. di), Theodor Mommsen e il Lazio antico. Giornata di Studi in memoria dell'illustre storico, epigrafista e giurista (Terracina, Sala Valadier, 3 aprile 2004), Roma, 2004, pp. 105-118.

D. Maras, Caratteri dell'epigrafia latina arcaica del Lazio meridionale, in L. Drago Troccoli (a c. di), Il Lazio dai Colli Albani ai Monti Lepini tra preistoria ed età moderna, Roma, 2009, pp. 431-439.

D. Maras, Interferenze culturali arcaiche etrusco-latine: la scrittura, in Della Fina, Giuseppe (a c. di), Gli Etruschi e Roma. Fasi monarchica e alto-repubblicana, Atti del XVI Convegno Internazionale di Studi sulla Storia e l'Archeologia dell'Etruria, Annali della Fondazione per il Museo «Claudio Faina», Orvieto-Roma, pp. 309331.

M. Muscariello, Influenze sulla nascita della scrittura nel Latium vetus: il latino arcaico, in Les Langues d'attestation fragmentaire dans l'espace méditerranéen au I ${ }^{\text {er }}$ millénaire avant notre ère: inscriptions, genres épigraphiques et analyse socio-linguistique, Atti del Convegno (Rouen 25-27 giugno 2012), Publications Universitaires de Rouen et du Havre, Rouen, in print.

A. Marinetti, Le iscrizioni sudpicene, Firenze, Olschki, 1985.

M. Pallottino, A proposito della nuova iscrizione latina arcaica di Satricum. Interventi sulla comunicazione del dott. Stibbe, «Archeologia Laziale» I («QuadAEI» I) (1978), pp. 98-99.

M. Pallottino, Lo sviluppo socio-istituzionale di Roma arcaica alla luce di nuovi documenti epigrafici, «Studi romani» 27 (1979), pp. 1-14.

M. Pallottino, Introduzione, in C. M. Stibbe, G. Colonna, C. De Simone, H. S. Versnel, Lapis Satricanus. Archaeological, epigraphical, linguistic and historical aspects of the new inscription from Satricum, Archeologische Studien van het Nederlands Instituut te Rome, Scripta Minora V, Staatsuitgeverij - 's-Gravenhage, The Hague,1980, pp. 13-7.

E. Peruzzi, On the Satricum Inscription, «PdP» XXXIII (1978), pp. 346-350.

V. Pisani, L'iscrizione paleolatina di Satricum, «Glotta» LIX (1981), pp. 136-140.

A. L. Prosdocimi, Studi sul latino arcaico, «REI» in «St. Etr.» XLVII (1979), pp. 183197 e 218-221.

A. L. Prosdocimi, Sull'iscrizione di Satricum, «Giornale Italiano di Filologia», XV, fasc. 2 (1984), pp. 183-230.

A. L. Prosdocimi, 'Sabinità' e (pan)italicità linguistica, «DArch», 5 (1987), pp. 53-64.

A. L. Prosdocimi, Satricum. I sodales del Publicola steterai a Mater (Matuta?), «PdP» XLIX (1994), pp. 365-377. 
G. Rocca, Tracce di sabinità nel Lapis Satricanus?, con Appendici a cura di G. Sarullo (I), E. Bozia - A. Barmpoutis (II), G. Trojsi (III) e L. Iozzoli (IV), in «Alessandria» 3 (2009), pp. 67-100.

D. Silvestri, I più antichi documenti epigrafici del latino, in E. Campanile (a c. di), Caratteri e diffusione del latino in età arcaica, Pisa, Giardini, 1993, pp. 97-118.

G. Sarullo, Boustrophedic writing on cippi, in Les Langues d'attestation fragmentaire dans l'espace méditerranéen au Ir millénaire avant notre ère: inscriptions, genres épigraphiques et analyse socio-linguistique, Proceeding of the Conference (Rouen $25^{\text {th }}-27^{\text {th }}$ of June 2012), Publications Universitaires de Rouen et du Havre, Rouen, in print.

C. M. Stibbe, Satricum, «Archeologia laziale» I («QuadAEI»I), Roma, Consiglio Nazionale delle Ricerche, 1978 , pp. 56-59.

C. M. Stibbe, G. Colonna, C. De Simone, H. S. Vernel, Lapis Satricanus. Archaeological, epigraphical, linguistic and historical aspects of the new inscription from Satricum, Archeologische Studien van het Nederlands Instituut te Rome, Scripta Minora V, Staatsuitgeverij - 's-Gravenhage, The Hague, 1980.

C. M. Stibbe, Nuovi e vecchi dati su Satricum, «Archeologia laziale» 4 («QuadAEI» 5), Roma, Consiglio Nazionale delle Ricerche, (1981), pp. 305-309.

C. M. Stibbe, Satricum ed $i$ Volsci, Satricana 2, Fondazione Centro di Studio Olandese per il Lazio, Tonden 1991.

M. Torelli, Il culto romano di Mater Matuta, «MededRom» LVI (1997), pp. 165-176.

D. Urbanová, La paleografia delle iscrizioni latine arcaiche, in XI Congresso Internazionale di Epigrafia Greca e Latina: Roma, 18-24 settembre 1997: Atti. I, Roma, Quasar, 1999, pp. 477-492.

H. S. Versnel, Historical implications, in C. M. Stibbe, G. Colonna, C. De Simone, H. S. Vernel, Lapis Satricanus. Archaeological, epigraphical, linguistic and historical aspects of the new inscription from Satricum, Archeologische Studien van het Nederlands Instituut te Rome, Scripta Minora V, Staatsuitgeverij - 'sGravenhage, The Hague, 1980, pp. 95-150.

H. S. Versnel, Die neue Inschrift von Satricum in historicher Sicht, «Gymnasium» 89 (1982), pp.193-235.

H. S. Versnel, IUN]IEI. A new conjecture in the Satricum Inscription, in M. Gnade - E. M. Moormann (a c. di), Satricum 1896-1996. Atti del convegno internazionale in occasione del primo centenario degli scavi a Satricum, Roma 1996, «MededRom» 56 (1997), pp. 177-197.

D. J. Waarsenburg, Lapis Satricanus. Nieuw licht op een oude foto, «Lampas» 29 (1996), pp. 5-9 (con riassunto in inglese).

D. J. Waarsenburg, Lapis Satricanus Minor. New light on an Old Photograph of the Lapis Satricanus, «AttiCltRom» (1997), pp. 198-200.

D. J. Waarsenburg, Un secolo di studi su Satricum. Saggio di ricerca bibliografica, «MededRom» 56 (1997), pp. 1-36.

D. J. Waarsenburg, Satricum. Cronaca di uno scavo. Ricerche archeologiche alla fine dell'800, Roma, Fratelli Palombi Editori, 1998. 